\title{
Analyst coverage: Does the listing location really matter?
}

\author{
Omaima A.G. Hassan ${ }^{\text {a }}$, Frank S. Skinner ${ }^{\text {b }}$ \\ a Aberdeen Business School, Robert Gordon University, UK \\ b Department of Economics and Finance, Brunel University, UK
}

\section{A R T I C L E I N F O}

\section{Article history:}

Received 12 May 2016

Accepted 21 May 2016

Available online 25 May 2016

\section{G12 \\ G14 \\ M4 \\ G230 \\ G240 \\ M490}

JEL classifications:

Keywords:

Analyst coverage

Analysts following

Security analyst

FTSE350

AIM

Alternative trading systems

\begin{abstract}
A B S T R A C T
Using a count panel regression method, we find that the listing location really does matter as stocks listed on the main board (FTSE350) rather than the junior market (AIM) attract more analyst coverage than can be explained by existing factors, even when we control for listing requirements and the type of cross-listing. We also find that listing requirements have a significantly greater impact on the number of analysts following AIM companies rather than their FTSE350 counterparts. Moreover, pooling stocks from different listing locations can conceal additional differences in the determinates of analyst services for the main board and junior markets. For example, cross-listing on a stock exchange increases analysts coverage for FTSE350 stocks but not AIM stocks and listing on less transparent trading venues such as over the counter and alternative trading systems (dark pools) decreases analyst coverage, especially for AIM stocks.
\end{abstract}

(C) 2016 The Authors. Published by Elsevier Inc. This is an open access article under the CC BY-NC-ND license (http://creativecommons.org/licenses/by-nc-nd/4.0/).

\section{Introduction}

It is crucial for managers to understand what influences analyst coverage since it is well documented that analyst coverage affects firm value. For example, Doukas, McKnigh, and Pantzalis (2005) and Jung, Sun, and Yang (2012) suggest that financial analysts facilitate more effective monitoring of the firms' activities, thereby reducing agency costs and increasing share value. Moreover, Baik, Kang, and Morton (2010) and Gotti, Han, Higgs, and Kang (2012) show that more analysts following increases firm value and reduces audit fees. In addition, Lang, Lins, and Maffett (2012) document higher liquidity and lower transaction costs when the number of analysts following a firm is higher. Li and You (2015) find that analysts create value for the firms they cover by increasing the demand for their common shares rather than monitoring or reducing information asymmetry.

Evidently, analyst coverage adds value to firms by signalling information about their performance and by increasing their visibility to investors, even when they do not actively add new information about these firms, but simply use existing information (Mola, Rau, \& Khorana, 2013). Therefore, analyst coverage is actively pursued by

E-mail addresses: o.hassan@rgu.ac.uk (O.A.G. Hassan), frank.skinner@brunel.ac.uk (F.S. Skinner). firms. For example, Anantharaman and Zhang (2011) provide evidence that managers value analyst coverage and are willing to expend resources to maintain a certain level of that coverage while Cliff and Denis (2004) find that firms are willing to compensate for analyst coverage through initial public offering premiums. Bushee and Miller (2012) note that some firms may resort to hiring investor relations professionals in order to pitch their business to security analysts while Kirk (2011) states that firms are prepared to buy research. Sibilkov, Straska, and Waller (2013) find that firms value analyst coverage and are prepared to strategically use the choice of merger and acquisition advisors to secure analyst coverage. Unsurprisingly, prior studies have tried to explore factors that drive analyst coverage, but mainly for the US market.

Our contribution is to highlight the influence of the marketplace for a company's shares on analyst coverage. Specifically, we examine the impact of three related aspects of listings on capital markets on analyst coverage. First, we examine whether listing on the main board (FTSE350) as opposed to the junior market (AIM) impacts the number of analysts following a stock. Second, we investigate whether the type of cross-listing such as listing on a stock exchange (SE), over the counter market (OTC) and alternative trading system (ATS) or "dark pools" is related to analyst coverage. Third, we examine whether listing requirements affects the number of analysts following a stock. 
Bhushan (1989) introduces a simple model where he suggests a number of firm characteristics that can impact analyst coverage. Following Bhushan (1989), subsequent empirical studies investigate the determinants of analyst coverage at both the country and firm levels. Multi-country studies examine the impact of different institutional environments on analyst coverage, such as investor protection, corporate governance (e.g., Baik et al., 2010; Boubakri \& Bouslimi, 2010; Bushman, Piotroski, \& Smith, 2004; Lang, Lins, \& Miller, 2004; Yu, 2010), and the effect of varying accounting standards for cross-listed stocks (e.g., Abdallah, Abdallah, \& Ismail, 2012; Chen, Weiss, \& Zheng, 2007). In firm-level studies, scholars examine the impact of different company characteristics and corporate governance issues on analyst following (e.g., Baik et al., 2010; Barth, Kasznik, \& McNichols, 2001; Bhushan, 1989; Brennan \& Hughes, 1991; Eng, Nabar, \& Mian, 2008; Jiraporn, Chintrakarn, \& Kim, 2012; Jiraporn, Liu, \& Kim, 2014; Lang \& Lundholm, 1996; Lehavy, Li, \& Merkley, 2011; Marston, 1997; Rajan \& Servaes, 1997; Sabherwal \& Smith, 2008).

In the UK context, Marston (1997) examines Bhushan's model for a sample of 251 firms listed on the main board in 1991. However, due to the unavailability of similar data on the main proxies (i.e., the number of analysts following, institutional holdings and insiders' holdings) to those employed in Bhushan (1989), Marston recommends repeating the study using all UK quoted companies to further examine the validity of Bhushan's model in the UK context. Hussain (2000) examines analyst coverage of the UK FTSE companies using a simultaneous equation framework to address the potential endogeneity problem between the number of analysts following and institutional ownership. However, the focus of these two studies is larger UK companies quoted on the main board so determinates of analysts following smaller and junior listed companies have not been previously investigated. In addition, both Hussain (2000) and Marston (1997) employ a classical linear regression model that does not suit datasets where the dependent variable (the number of analysts following a firm) is a discrete variable that takes only a finite number of nonnegative integers (Rock, Sedo, \& Willenborg, 2001).

A review of prior studies shows more gaps in the current literature, which provides further motivation for this study. Firstly, the literature is mainly informed by US studies. This study covers the UK market, which is structurally different from the US market in an important aspect that is relevant to the demand for analyst services. Specifically, only $10.7 \%$ of listed equity in the UK is owned by individuals (Office of National Statistics, 2012), whereas the comparable figure for the US is $36.5 \%$ (US Census, 2012). This implies a higher concentration of institutional holdings in the UK as opposed to the US (ICAEW, 2007). This is important because the number of institutions and the percentage ownership held by institutions has been shown to be important determinants of the demand for analyst services in prior studies.

Secondly, although the sample constituents covered in prior studies sometimes belong to different listing locations (main market versus junior market); none has examined the possibility that the determinants of analyst coverage can be conditional on listing location. For instance, while Brennan and Hughes (1991), Chen et al. (2007) and Jiraporn et al. (2012) include main board NYSE/AMEX and junior market NASDAQ firms in their sample and Giraldo (2011) include stocks traded on six different trading venues including NYSE, NASDAQ and OTC, they do not examine whether the determinates of analyst services differ by listing location. Meanwhile, Baik et al. (2010), Jiraporn et al. (2014) and Rajan and Servaes (1997) include listed and non-listed firms in their sample and add a dummy for listing versus non-listed firms. This is a different issue than listing on the main board as opposed to the junior market partly because the hurdle from moving to the main board from the junior market is much lower than issuing an initial public offering. Moreover, we divert from prior studies by explicitly examining the impact of different listing requirements for listing on the main board as opposed to the junior market on analyst coverage. These include market capitalisation and free float.

Thirdly, unlike prior studies, we examine the effect of cross-listings on stock exchanges, over the counter markets and alternative trading systems on analyst coverage. The salient difference among the three types of trading venues is transparency where stock exchanges allow dealers to see the full order book ${ }^{1}$ whereas over the counter and especially alternative trading systems (dark pools) provide much less information on the demand and supply of shares. The potential impact of these different trading systems is especially important given the rise of alternative trading systems and the development of the London Stock Exchange to what is now popularly known as the world's premier international stock exchange. ${ }^{2}$

The current study examines the impact of listing location on analyst coverage using count data panel regressions that adjust for the count nature of the dependent variable as do Boubaker and Labégorre (2008) and Rock et al. (2001), but for more recent, non-US panel data. We employ count panel regression methods for a sample of 1194 UK listed companies from 2010 to 2015 . The use of panel data provides a number of advantages over both the traditional cross-sectional and time-series analyses. It gives the researcher a larger number of observations, thus increasing the degrees of freedom for any statistical testing and lessening the problem of multicollinearity among the explanatory variables (Hsiao, 2002), thereby improving the efficiency of estimates.

We first include a dummy variable for the listing location to see if there is something special about being listed on the main board. We find that the location dummy is positive and highly significant. Moreover, it is clear that cross-listing on stock exchanges is positive but cross-listings on less transparent over the counter and alternative trading systems are inversely related to analyst coverage.

This means that stocks listed on the main board attract more analyst coverage than can be explained by existing factors. The question now is whether the listing requirements can explain this? To answer this question, we separately investigate how additionally controlling for differences in market capitalisation and free float changes the coefficient on the listing location dummy variable. We also conduct this examination for the main and junior markets individually to examine whether stocks from the main board and the junior market can be pooled together in the same dataset. In other words, we investigate whether the demand and supply functions for analyst services are the same for the main board and junior market stocks.

We find that market capitalisation positively impacts analyst coverage and that impact is significantly higher for the AIM companies. We also find that free float has a positive impact on the total and the AIM samples yet free float is inversely related to the number of analysts following for the FTSE350 sample. The difference in the impact of free float between the two markets is statistically significant. Together, the significant difference in the influence of market capitalisation and free float between the main board and the junior market hint that the demand and supply of analyst's services do vary by listing location so caution is advisable when suggesting which factors for analyst services are operative for pooled samples of main board and junior market stocks. Still, even when controlling for market capitalisation, free float and type of cross-listing, listing on the main board as opposed to the junior market has a significant positive influence on the number of analysts following a company.

The remainder of this paper is organised as follows. In Section 2, we develop our hypotheses. The model is presented in Section 3 while Section 4 describes the sample and discusses the results. Section 5 provides concluding remarks.

\section{Hypothesis development}

Individuals hold a larger portion of AIM companies than main board listed companies due to holdings by directors (Office of National Statistics, 2012). Accordingly, we expect that ownership dispersion is

\footnotetext{
When dealers can see the full order book they can see the price and the quantity at all levels of the bid and ask. That is, the dealers can see the supply and demand curves for the shares.

${ }^{2}$ See http://www.world-stock-exchanges.net/.
} 
greater for FTSE350 companies compared to AIM companies. Clatworthy and Peel (2007) suggest that the likelihood of information asymmetry and agency problems on the main market is higher than that on the AIM market due to greater ownership dispersion of FTSE350 companies. As the level of information asymmetry and agency problems among the management of the firm and outside providers of funds increases, the demand for analyst services will increase. Therefore, our first hypothesis is as follows:

\section{H1. Analyst coverage is expected to be positively associated with listing on the main board.}

Companies listed on the London Stock Exchange are subject to different eligibility rules depending on whether the company is listed on the main market (FTSE350) or on the junior market (AIM). Specifically, to be listed on the main market, a company must have at least $£ 700 \mathrm{k}$ in market capitalisation, a three-year trading record and at least $25 \%$ of its shares must be in public hands (free float). ${ }^{3}$ In contrast, AIM companies have no requirements for a minimum market capitalisation or a minimum percentage of free float. Recent market statistics (London Stock Exchange Group, 2014a, 2014b) show that FTSE350 listed companies have a much larger capitalisation than AIM companies because about $87 \%$ of FTSE companies have a market value greater than two billion pounds, whereas only $11.7 \%$ of the AIM companies have a market capitalisation of one billion pounds or more.

Free float is the number of shares that is available to the public relative to the number of shares outstanding. The number of shares available to the public is calculated by subtracting the shares held by insiders and those deemed to be stagnant shareholders from the shares outstanding. ${ }^{4}$ A higher percentage of the free float means more active stocks will be available to the public, thereby increasing investors' base. A larger investor base will imply more transactions business to attract more analyst coverage. Therefore, our second hypothesis is as follows:

H2. Companies with higher market capitalisation and higher percentages of free float are expected to attract more analyst coverage.

\section{Research model}

Bhushan (1989) suggests that the equilibrium total expenditure by investors on analyst services for a particular firm in a given period is a function of various firm characteristics that can either affect the aggregate demand for or supply of analyst services or both. He assumes that both the aggregate demand and supply functions are continuous and twice differentiable in all their arguments. He also assumes that the demand curve is downward sloping and the supply curve is upward sloping, thus:

$\mathrm{TC} *(\mathrm{k} 1, \mathrm{k} 2, \ldots, \mathrm{kn})=\mathrm{P} *(\mathrm{k} 1, \mathrm{k} 2, \ldots, \mathrm{kn}) \mathrm{Q} *(\mathrm{k} 1, \mathrm{k} 2, \ldots, \mathrm{kn})$

In (1), $\mathrm{TC}^{*}$ is the equilibrium total expenditure by investors on analyst services for a particular firm in a given period, $\mathrm{Q}^{*}$ is the corresponding equilibrium of the aggregated demand for analyst services for the firm during this period, $\mathrm{P}^{*}$ is the equilibrium price and $\mathrm{k} 1, \mathrm{k} 2, \ldots, \mathrm{kn}$ are the $\mathrm{n}$ company characteristics $\mathrm{k}$. Using comparative statics, Bhushan (1989) deduced that the effect of any firm characteristic $\mathrm{k}$ on

\footnotetext{
${ }^{3}$ Moreover, main market firms are required, but AIM listed firms are not required, to adhere to the UK Corporate Governance Code. Unfortunately, we were unable to collect much data for AIM firms as AIM companies typically do not file information concerning governance. We did collect what was available for FTSE and AIM companies and find that the sample is severely depleted (with only 122 AIM firm-year observations) and the compliance variable was never statistically significant. This is likely because most FTSE companies have a high degree of code compliance, so there is little variation in the data. In any event, even when we include the compliance variable, our empirical results are not materially different from what are reported here.

${ }^{4}$ Stagnate shareholders include employee benefit trusts, corporations that are not actively managing money, venture capital companies and governments.
}

the equilibrium total expenditure by investors on analyst services depends on the respective price elasticity of aggregate demand and supply. A change in a firm characteristic $\mathrm{k}$ can result in a shift in either the demand curve or the supply curve or both. Bhushan (1989) assumes that the aggregate demand for analyst services is elastic given that the demand for securities is highly elastic. This, in turn, means that if the price of analyst services for a particular firm increases slightly, then investors can change their investment portfolios, replacing a security with other close substitutes that have less expensive analyst services.

Bhushan (1989) considers a number of company characteristics that can affect either the demand for or the supply of analyst services or both. These firm characteristics are: ownership structure, firm size, returns variability, the number of lines of business and the correlation between firm return and market return. In addition, Bhushan (1989) considers the effect of industry type in his model.

Hussain (2000) suggests that the number of analysts following and the percentage of shares owned by institutions can be endogenous because the percentage ownership by institutions is also inversely related to another independent variable, i.e. the percentage ownership by insiders. However, Hussain (2000) did not specifically examine whether endogeneity is an empirical issue. Meanwhile, Baik et al. (2010) observe that firm size and the number of analysts following can be simultaneously determined because analyst coverage can lead to higher valuations and analysts are more likely to follow firms with higher values. Baik et al. (2010) also did not specifically test for endogeneity but noted that endogeneity is not likely to be a problem because OLS estimates were similar to their simultaneous equation estimates. Therefore, we are motivated to test for possible endogeneity between the number of analysts following and institutional ownership on the one hand, and the number of analysts following and firm size, on the other hand, using a Hausman (1978) specification test. We find that the Hausman derived fitted values for institutional ownership and the Hausman derived fitted values for firm size are not significantly related to the number of analysts following in the corresponding structural equation. Therefore, like Baik et al. (2010), we conclude that endogeneity is not an issue so that a separate equation for the percentage ownership by institutions or for market value is not appropriate. ${ }^{5}$

Therefore, we proceed with Bhushan's (1989) model and include two proxies for institutional ownership, the number of institutions holding shares in a company (NINST) and the percentage of institutional holdings (\%INST). Institutional ownership is expected to affect both the demand for and the supply of analyst services, but the direction of its effect is not obvious (Bhushan, 1989). If acquiring analyst service is not cost effective for individual investors, more concentrated institutional ownership may imply an increase in the demand for analyst services. However, more concentrated institutional ownership may increase the demand for in-house monitoring rather than outside monitoring via external analyst services. Meanwhile, \%INSID is the percentage of insiders holding. Assuming that the demand for analyst services comes mainly from outside providers of funds, and assuming that concentrations in insiders' ownership do not induce agency conflicts among majority and minority shareholders, an increase in insiders' ownership implies a decrease in demand for analyst services (Bhushan, 1989). In addition, we include stock price volatility (VOL) because if analyst information and public information are more useful in predicting future return than public information alone, then higher return variability is expected to increase the demand for analyst services. Thus, Bhushan (1989) expects the aggregate demand for analyst services to be an increasing function of a firm's return variability, assuming that the cost of information acquisition for firms with higher return variability is not significant. Moreover, the number of segments (NSEG) is used to proxy for the number of lines of business. We expect that as the number of business segments increase, the number of analysts following will

\footnotetext{
${ }^{5}$ See Brooks (2002) pages 328-330. The details of these Hausman endogeneity tests are available from the corresponding author upon request.
} 
decrease as the firm will become more complex, and therefore more costly to follow.

We also extend Bhushan's (1989) model to include additional firm characteristics recommended by later studies. First, we introduce a variable (NLISTING) to control for the number of cross-listing since it was suggested by Marston (1997) that it affects analyst coverage for UK companies. There are two competing possible effects for cross-listing. First, cross-listing in foreign exchanges can increase firm visibility and remove barriers for foreign investors to invest in the company, thereby widening investors' base and increasing the demand for analyst services (Marston, 1997). Second, cross-listing in foreign exchanges implies an increased level of operating activities in the international product markets making these firms more opaque for analysts. This, in turn, means that analysts will find it harder to produce forecasts about these firms, which can discourage some analysts from following them, resulting in a decrease in the number of analysts following (Eng et al., 2008, p.30). Therefore, the sign of the relationship between NLISTING and NANAL is an empirical issue.

We also suggest that the type of cross-listing itself can affect the demand for analyst services. Stock markets are transparent where all dealers can see the order book, the price and quantity details of the supply and demand of shares, in real time. Similarly, in over the counter markets, at least subsets of the dealers can see a portion of the order book. However, in recent years, we have seen the rise in popularity of alternative trading systems (dark pools) that allows investors to trade off the traditional markets so that the trade itself is less likely to move prices. Only after the trade has been executed will the trade be reported to the relevant authorities. The impact of dark pools and over the counter markets on the demand for analysts' services is uncertain. On the one hand, it is possible that investors can feel that the price of stocks that often trade in less transparent markets is less fair and be less willing to invest in them and engage analyst services. On the other hand, alternative trading systems and over the counter markets increase the number of venues for the sale of shares and so could attract additional analysts coverage. Therefore, we separately examine the impact of stock exchange, over the counter market and alternative trading system cross-listings on analyst coverage.

We also consider three more variables that might affect analyst coverage, namely: firm profitability, systematic risk and audit firm size. We examine the impact of firm profitability on analyst coverage since prior studies suggest that analysts will be reluctant to follow non-profitable companies (e.g., Baik et al., 2010; Boubaker \& Labégorre, 2008; Jiraporn et al., 2014). Firm profitability is measured by return on equity (ROE). We also examine the impact of systematic risk on analyst coverage and use the market beta (BETA) to proxy for a firm's systematic risk.
A firm's systematic risk may impact analyst activity through the institutional clientele effect which in turn could affect a firm's disclosure policy (Baik et al., 2010; Boubaker \& Labégorre, 2008; Hussain, 2000). Therefore, we expect a positive association between market beta and analyst coverage for UK listed companies.

Audit firm size (BIG4) is often used in prior studies as a surrogate for audit quality (e.g., Chen, Chen, Lobo, \& Wang, 2011; Tendeloo \& Vanstraelen, 2008). This line of research can be interpreted as either large auditors provide higher quality audits as they have more wealth and reputational risk (DeAngelo, 1981; Ireland, 2003), or that small auditors supply low levels of audit quality (DeFond \& Francis, 2005). Smaller accounting firms report less conservatively as they issue fewer non-clean audit reports and their clients are more likely to have abnormal accruals, which is suggestive of more aggressive earnings management. Credible financial reporting and high-quality earnings may reduce the costs of collecting and analysing public financial disclosures and may help financial analysts produce better forecasts, attracting more clients, which will increase the demand for analyst services. BIG4 is a dummy variable that takes the value of one if the auditor is one of the four dominant accounting firms and zero otherwise. Therefore, our initial model is as follows.

$$
\begin{aligned}
& \text { NANAL }_{i t}=b_{0}+b_{1} \operatorname{Ln}\left(1+\text { NINST }_{i t}\right)+b_{2} \operatorname{Ln}\left(1+\% \text { INST }_{\text {it }}\right) \\
& +b_{3} \operatorname{Ln}\left(1+\% \operatorname{INSID}_{i t}\right)+b_{4} \text { VOL }_{i t}+b_{5} \operatorname{Ln}\left(1+\text { NSEG }_{i t}\right) \\
& \left.+\mathrm{b}_{6} \text { Ln (NLISTING }{ }_{i t}\right)+\mathrm{b}_{7} \text { BIG }_{\text {it }}+\mathrm{b}_{8} \text { BETA }_{\mathrm{it}}+\mathrm{b}_{9} \text { ROE }_{\mathrm{it}} \\
& +\mathrm{b}_{10} \mathrm{MRT}_{\text {it }}+\mathrm{b}_{11} \operatorname{Ln}\left(\mathrm{TA}_{\mathrm{it}}\right)+\mathrm{b}_{12} \text { Industry dummy } \mathrm{it}_{\mathrm{it}} \\
& +\varepsilon_{\text {it }}
\end{aligned}
$$

The detailed description and the expected sign of all the dependent variables are summarised in Table 1.

We test our hypotheses by firstly introducing a dummy variable (MRT) that takes the value of one for listing on the main board (FTSE350), and zero otherwise, to examine the effect of the listing location on analyst coverage for the total sample. In addition, we run the same regression for the FTSE350 and AIM markets individually. Secondly, we consecutively replace the total number of cross-listings (NLISTING) with the number of cross-listings on SE, OTC and ATS to separately examine the impact of changes in the transparency of the trading venue on analyst coverage overall and on the main board and junior markets separately. Thirdly, we replace total assets (TA) with market capitalisation (MCAP) to determine whether it is firm size as measured by total assets or firm size as determined by the listing requirement that influences the number of analysts following. Finally, we introduce free float (FLOAT) to check the impact on the dummy var-

\begin{tabular}{|c|c|c|}
\hline Variable & $\begin{array}{l}\text { Expected } \\
\text { sign }\end{array}$ & Description \\
\hline NINST & $+/-$ & The number of Institutional stock holders \\
\hline \%INST & $+1-$ & The percentage of outstanding shares held by institutional investors \\
\hline \%INSID & - & The percentage of outstanding shares held by insiders \\
\hline VOL & + & The standard deviation of the relative price change for the 360 calendar days closing price, expressed as a percentage \\
\hline NSEG & - & The number of recorded business segments \\
\hline NLISTING & $+1-$ & The number of cross-listing \\
\hline SE & $+1-$ & The number of cross-listings on traditional stock exchanges \\
\hline OTC & $+1-$ & The number of over the counter cross-listings \\
\hline ATS & $+1-$ & $\begin{array}{l}\text { The number of cross-listings on alternative trading systems (dark pools) including electronic communication networks (ECNs), } \\
\text { multi-trading facility MTF, crossing networks and call markets. }\end{array}$ \\
\hline BIG4 & + & A dummy variable that takes the value of one if the auditor is one of the four dominant accounting firms and zero otherwise. \\
\hline BETA & + & The market model beta for each stock measured via the market model using weekly data. \\
\hline ROE & + & Return on Equity in percentage, calculated as (net income available for common shareholders / average total common equity) \\
\hline MCAP & + & The market value of equity of the firm at the fiscal year-end \\
\hline TA & + & Total assets \\
\hline Float & + & The percentage of shares that is available to the public \\
\hline Industry dummies & $+1-$ & A dummy variable that takes the value of 1 for the relevant industry and 0 otherwise. \\
\hline
\end{tabular}
iable for listing location (MRT) to determine, along with market

Table 1

List of variables.

This table reports the definition of the independent variables and the expected sign of the relationship with NANAL, number of analysts making recommendations for a stock. 
Table 2A

Descriptive analysis.

This table reports the sample statistics for the combined, FTSE350 and AIM listed samples.

\begin{tabular}{|c|c|c|c|c|c|c|c|}
\hline & Mean & Median & Max. & Min. & STD & Skewness & Kurtosis \\
\hline \multicolumn{8}{|c|}{ Total sample of 3485 firm-year observations } \\
\hline NANAL & 7.53 & 3.00 & 50.00 & 0.00 & 8.90 & 1.24 & 3.65 \\
\hline NINST & 162.05 & 87.00 & 1214.00 & 0.00 & 180.50 & 2.12 & 8.11 \\
\hline \%INST & 78.64 & 88.94 & 100.00 & 0.00 & 25.86 & -1.23 & 3.59 \\
\hline \%INSID & 14.76 & 4.17 & 100.00 & 0.00 & 21.86 & 2.02 & 6.78 \\
\hline VOL & 46.55 & 35.38 & 978.63 & 5.85 & 45.07 & 7.53 & 100.56 \\
\hline NSEG & 1.82 & 1.00 & 14.00 & 0.00 & 1.57 & 2.26 & 13.24 \\
\hline NLISTING & 23.58 & 26.00 & 48.00 & 0.00 & 12.53 & -0.32 & 1.97 \\
\hline SE & 3.90 & 3.00 & 13.00 & 0.00 & 2.24 & 0.87 & 3.78 \\
\hline OTC & 11.03 & 16.00 & 20.00 & 0.00 & 7.49 & -0.38 & 1.26 \\
\hline ATS & 8.65 & 8.00 & 18.00 & 0.00 & 4.37 & -0.35 & 2.60 \\
\hline BIG4 & 0.65 & 1.00 & 1.00 & 0.00 & 0.48 & -0.63 & 1.39 \\
\hline BETA & 0.73 & 0.70 & 2.86 & -0.91 & 0.36 & 0.38 & 4.42 \\
\hline ROE & 3.52 & 8.62 & 2409.86 & -1370.85 & 73.71 & 11.90 & 454.45 \\
\hline $\operatorname{MCAP}(\mathrm{M} £)$ & 2605.92 & 112.15 & $124,730.00$ & 0.33 & 9719.55 & 6.62 & 54.48 \\
\hline $\mathrm{TA}(\mathrm{M} £)$ & $12,967.30$ & 112.97 & $1,690,610.00$ & 0.05 & $105,145.70$ & 12.27 & 166.09 \\
\hline FLOAT (\%) & 74.28 & 79.23 & 100.00 & 0.90 & 22.34 & -0.70 & 2.49 \\
\hline
\end{tabular}

capitalisation (MCAP), if listing eligibility for the main board can account for the influence of listing location.

\section{Research sample and results}

\subsection{Research sample}

The data for this study are collected from the Bloomberg database. Our initial sample consists of all firms listed on the London Stock Exchange. The initial sample consists of 1267 UK listed companies from 2010 to 2015 with a maximum 7602 firm-year observations. The actual sample size depends on the availability of information about each variable included in the regression model, so that we finally end up with 1194 firms with a common sample of 3485 firm-year observations. This includes 351 FTSE350 companies with 1403 firm-year observations and 843 AIM companies with 2082 firm-year observations.

\subsection{Descriptive analysis}

Table $2 \mathrm{~A}$ provides the descriptive analysis for the entire sample. It shows that the average number of analysts following a UK listed company (NANAL) is eight while the median is three. The percentages of shares held by institutions (\%INST) and insiders (\%INSID) for an average UK listed company are about $79 \%$ and $15 \%$ respectively. This implies that the UK listed companies are mostly owned by institutions with 162 institutions (NINST) on average holding shares in a firm. This observation is consistent with the Office of National Statistics (2012), which reports that only $10.7 \%$ of all UK shares are held by individual investors.

Additionally, the average UK listed company is cross-listed on 24 trading venues worldwide, 4 of which are stock exchanges. Marston (1997) reports the average number of cross-listings as 0.47 so clearly the number of cross-listings has increased dramatically over the years as the London stock exchange developed into the world's premiere stock exchange. The average company is listed more on over the counter markets (11) than on alternative trading systems (9) and has 2 recorded segments with return variability (VOL) of $47 \%$. The difference between the minimum and the maximum value of each variable reflects the huge variation in the composition of the sample. For example, the market capitalisation of the companies included in the sample varies from $£ 0.33$ to $£ 124,730$ million suggesting that companies of radically different sizes are included in the sample. Moreover, free float ranges from $0.90 \%$ to $100 \%$. This suggests that outliers ${ }^{6}$ might form a problem.

\footnotetext{
${ }^{6}$ We also winsorize the dataset in order to reduce the impact of outliers and re-run the analysis. The qualitative results are similar to those obtained here; therefore we decided to use the original data.
}

Therefore, we use the natural logarithm of each variable where practical.

Table 2B, panels A and B, break down the descriptive statistics into the FTSE350 and AIM sub-samples respectively. The two samples do look radically different. We find that AIM firms are much smaller, with fewer analysts following, fewer institutions holding a smaller ownership stake, fewer business segments, fewer cross-listings of all types, lower systematic risk, lower profitability, lower free float and fewer companies that were audited by one of the Big4 accounting firms. However, insiders' ownership stakes are larger, and AIM firms have much higher return volatility. In results not tabulated here, we compared the differences in the means for all variables between the FTSE350 companies and their AIM counterparts and they show significant differences for all the variables at the $1 \%$ level of significance (two-tailed test). ${ }^{7}$ This suggests that these two groups of companies are significantly different.

\subsection{The correlation matrix}

Table 3 reports the results of Pearson correlation test among the variables. It shows that the number of analysts following a firm (NANAL) has a significant association with almost all the explanatory variables in line with prior expectation except VOL and NSEG. The correlation table indicates that the number of analysts following is increasing with institutional holdings (NINST; \%INST), market segments (NSEG), foreign stock exchange listings of all types (NLISTING, SE, OTC and ATS), Big4 auditing (BIG4), systemic risk (BETA), return on equity (ROE), main market listing (MRT), total assets (TA), market capitalisation (MCAP) and free float (FLOAT) but decreasing in insiders' holdings (\%INSID) and stock volatility (VOL).

The association between NANAL and NSEG is positive and significant contrary to prior expectations. The results also show a negative and significant association between VOL and NANAL. However, these results only focus on the association between a pair of variables; a multiple regression analysis may yield different conclusions.

The correlation between firm size TA and NINST is positive and significant (0.373), indicating that larger firms attract more institutional holdings. In addition, the correlation between TA and \%INSID is negative and significant $(-0.081)$ indicating that smaller firms are more closely held by insiders. The correlation between TA and each of NSEG, NLISTING, SE, OTC, ATS, BIG4, BETA, FLOAT is positive and significant, indicating that larger firms have more segments, are more widely cross-

\footnotetext{
${ }^{7}$ These results are available from the corresponding author upon request.
} 
Table 2B

Descriptive analysis.

This table splits the sample statistics into the main board FTSE350 listed and junior market AIM listed sub-samples.

\begin{tabular}{|c|c|c|c|c|c|c|c|}
\hline \multicolumn{8}{|c|}{ Panel A: FTSE350 sample of 1403 firm-year observations } \\
\hline NANAL & 16.14 & 16.00 & 50.00 & 0.00 & 8.02 & 0.45 & 2.89 \\
\hline NINST & 315.33 & 244.00 & 1214.00 & 11.00 & 198.91 & 1.44 & 5.14 \\
\hline \%INST & 90.34 & 100.00 & 100.00 & 2.44 & 16.08 & -2.15 & 7.71 \\
\hline \%INSID & 5.79 & 0.66 & 100.00 & 0.00 & 14.98 & 3.99 & 20.44 \\
\hline VOL & 33.16 & 28.67 & 252.55 & 14.36 & 20.84 & 5.48 & 43.64 \\
\hline NSEG & 2.65 & 2.00 & 14.00 & 0.00 & 1.87 & 2.00 & 10.85 \\
\hline NLISTING & 33.84 & 35.00 & 48.00 & 0.00 & 9.29 & -2.46 & 9.26 \\
\hline SE & 5.15 & 5.00 & 13.00 & 0.00 & 2.51 & 0.37 & 2.90 \\
\hline OTC & 16.31 & 18.00 & 20.00 & 0.00 & 4.40 & -2.93 & 10.29 \\
\hline ATS & 12.37 & 13.00 & 17.00 & 0.00 & 3.51 & -2.61 & 9.81 \\
\hline BIG4 & 0.97 & 1.00 & 1.00 & 0.00 & 0.16 & -5.91 & 35.95 \\
\hline BETA & 0.96 & 0.93 & 2.16 & -0.02 & 0.28 & 0.60 & 3.90 \\
\hline ROE & 24.22 & 15.85 & 2409.86 & -172.77 & 90.91 & 18.55 & 429.41 \\
\hline $\operatorname{MCAP}(\mathrm{M} £)$ & 6353.70 & 1543.47 & $124,730.00$ & 9.43 & $14,531.86$ & 4.14 & 22.43 \\
\hline $\mathrm{TA}(\mathrm{M} £)$ & $32,076.48$ & 1792.30 & $1,690,610.00$ & 38.54 & $163,895.10$ & 7.70 & 66.27 \\
\hline FLOAT $(\%)$ & 86.13 & 94.85 & 100.00 & 2.07 & 18.47 & -1.64 & 4.85 \\
\hline \multicolumn{8}{|c|}{ Panel B: AIM sample of 2082 firm-year observations } \\
\hline NANAL & 1.72 & 1.00 & 25.00 & 0.00 & 2.33 & 3.73 & 24.87 \\
\hline NINST & 58.76 & 56.00 & 325.00 & 0.00 & 37.11 & 0.96 & 5.92 \\
\hline \%INST & 70.75 & 77.34 & 100.00 & 0.00 & 28.13 & -0.79 & 2.58 \\
\hline \%INSID & 20.81 & 11.09 & 100.00 & 0.00 & 23.62 & 1.56 & 4.90 \\
\hline VOL & 55.58 & 44.32 & 978.63 & 5.85 & 53.90 & 6.73 & 77.12 \\
\hline NSEG & 1.26 & 1.00 & 6.00 & 0.00 & 0.99 & 1.34 & 5.64 \\
\hline NLISTING & 16.66 & 15.00 & 37.00 & 0.00 & 9.27 & -0.16 & 2.02 \\
\hline SE & 3.06 & 3.00 & 7.00 & 0.00 & 1.54 & 0.48 & 2.73 \\
\hline OTC & 7.46 & 3.00 & 20.00 & 0.00 & 7.02 & 0.49 & 1.37 \\
\hline ATS & 6.14 & 7.00 & 18.00 & 0.00 & 2.82 & -1.10 & 4.76 \\
\hline BIG4 & 0.43 & 0.00 & 1.00 & 0.00 & 0.50 & 0.28 & 1.08 \\
\hline BETA & 0.59 & 0.54 & 2.86 & -0.91 & 0.33 & 0.85 & 7.21 \\
\hline ROE & -10.44 & 1.81 & 175.59 & -1370.85 & 55.18 & -9.68 & 196.91 \\
\hline $\operatorname{MCAP}(\mathrm{M} £)$ & 80.39 & 29.71 & 3922.60 & 0.33 & 194.22 & 8.69 & 117.88 \\
\hline $\mathrm{TA}(\mathrm{M} £)$ & 90.18 & 34.89 & 7822.20 & 0.05 & 353.49 & 17.03 & 328.29 \\
\hline FLOAT(\%) & 66.30 & 68.73 & 100.00 & 0.90 & 21.15 & -0.43 & 2.38 \\
\hline
\end{tabular}

listed on trading venues of all types, are more likely to be audited by one of the Big4 accounting firms, have higher systematic risk and are more in public hands. The correlation between firm size TA and return variability (VOL) is negative but not significant. Most of these results correspond to the results obtained by Bhushan (1989) and Marston (1997). Table 3 also shows that there are other significant correlations among the explanatory variables. However, the use of panel data analysis should reduce the impact of multicollinearity on the regression results (Hsiao, 2002). In addition, the reported VIF values suggest that multicollinearity is not an issue for this study.

\subsection{Multiple regression analysis}

The Poisson model is a count data regression model, which corrects for the discrete, count data nature of our dependent variable and is especially suitable when the conditional mean and variance of the dependent variable are equal. If the equality of the conditional mean and variance does not hold, then the standard errors generated by the Poisson model will be underestimated thereby incorrectly reporting high levels of significance. In this case, a negative binomial count (NBC) regression model is more suitable (Rock et al., 2001).

Table 3

Pearson correlation for the common sample (3485 firm-year observations).

\begin{tabular}{|c|c|c|c|c|c|c|c|c|c|c|c|c|c|c|c|c|}
\hline & NANAL & NINST & \%INST & \%INSID & VOL & NSEG & NLISTING & SE & OTC & ATS & BIG4 & BETA & ROE & MCAP & TA & FLOAT \\
\hline NANAL & 1 & & & & & & & & & & & & & & & \\
\hline NINST & $.878^{* *}$ & 1 & & & & & & & & & & & & & & \\
\hline \%INST & $.313^{* *}$ & $.323^{* *}$ & 1 & & & & & & & & & & & & & \\
\hline \%INSID & $-.332^{* *}$ & $-.342^{* *}$ & $-.340^{* *}$ & 1 & & & & & & & & & & & & \\
\hline VOL & $-.233^{* *}$ & $-.212^{* *}$ & $-.211^{* *}$ & $-.039^{*}$ & 1 & & & & & & & & & & & \\
\hline NSEG & $.442^{* *}$ & $.482^{* *}$ & $.165^{* *}$ & $-.137^{* *}$ & $-.190^{* *}$ & 1 & & & & & & & & & & \\
\hline NLISTING & $.611^{* *}$ & $.594^{* *}$ & $.175^{* *}$ & $-.238^{* *}$ & $-.177^{* *}$ & $.365^{* *}$ & 1 & & & & & & & & & \\
\hline SE & $.659^{* *}$ & $.695^{* *}$ & $.159^{* *}$ & $-.275^{* *}$ & $-.100^{* *}$ & $.378^{* *}$ & $.711^{* *}$ & 1 & & & & & & & & \\
\hline OTC & $.452^{* *}$ & $.425^{* *}$ & $.106^{* *}$ & $-.178^{* *}$ & $-.140^{* *}$ & $.256^{* *}$ & $.931^{* *}$ & $.464^{* *}$ & 1 & & & & & & & \\
\hline ATS & $.641^{* *}$ & $.620^{* *}$ & $.238^{* *}$ & $-.236^{* *}$ & $-.217^{* *}$ & $.415^{* *}$ & $.909^{* *}$ & $.732^{* *}$ & $.720^{* *}$ & 1 & & & & & & \\
\hline BIG4 & $.506^{* *}$ & $.446^{* *}$ & $.425^{* *}$ & $-.277^{* *}$ & $-.195^{* *}$ & $.288^{* *}$ & $.386^{* *}$ & $.330^{* *}$ & $.309^{* *}$ & $.409^{* *}$ & 1 & & & & & \\
\hline BETA & $.505^{* *}$ & $.438^{* * *}$ & $.251^{* *}$ & $-.285^{* *}$ & -.003 & $.210^{* *}$ & $.365^{* *}$ & $.384^{* *}$ & $.281^{* *}$ & $.369^{* *}$ & $.328^{* *}$ & 1 & & & & \\
\hline ROE & $.205^{* *}$ & $.167^{* *}$ & $.137^{* *}$ & .007 & $-.182^{* *}$ & $.111^{* *}$ & $.153^{* *}$ & $.065^{* *}$ & $.126^{* *}$ & $.191^{* * *}$ & $.162^{* *}$ & $.060^{* *}$ & 1 & & & \\
\hline MCAP & $.568^{* *}$ & $.742^{* *}$ & .025 & $-.159^{* *}$ & $-.118^{* *}$ & $.371^{* *}$ & $.347^{* *}$ & $.509^{* *}$ & $.223^{* *}$ & $.354^{* *}$ & $.191^{* *}$ & $.187^{* *}$ & $.073^{* *}$ & 1 & & \\
\hline $\mathrm{TA}$ & $.302^{* *}$ & $.373^{* *}$ & .008 & $-.081^{* *}$ & -.028 & $.339 * *$ & $.195^{* *}$ & $.313^{* *}$ & $.121^{* *}$ & $.191^{* * *}$ & $.090^{* *}$ & $.185^{* *}$ & .006 & $.534^{* *}$ & 1 & \\
\hline FLOAT & $.415^{* *}$ & $.441^{* *}$ & $.357^{* *}$ & $-.555^{* *}$ & $-.070^{* *}$ & $.207^{* *}$ & $.339^{* *}$ & $.323^{* *}$ & $.257^{* *}$ & $.368^{* *}$ & $.320^{* *}$ & $.337^{* *}$ & $.077^{* *}$ & $.174^{* *}$ & $.045^{* *}$ & 1 \\
\hline VIF & & 5.148 & 1.493 & 1.571 & 1.156 & 1.398 & 1.706 & 2.029 & 1.313 & 1.844 & 1.485 & 1.412 & 1.077 & 3.241 & 1.510 & 1.720 \\
\hline
\end{tabular}

\footnotetext{
**. Correlation is significant at the 0.01 level (2-tailed). * Correlation is significant at the 0.05 level (2-tailed). VIF is the variance inflation factor for each variable.
} 
Table 4

The impact of listing location on analyst coverage.

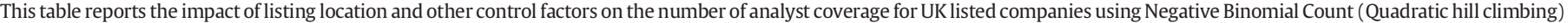
and GLM Robust Standard Errors \& Covariance. It considers firm size as measured by the natural logarithm of total assets.

\begin{tabular}{|c|c|c|c|c|c|c|c|c|}
\hline Variable & Expected sign & Total all & FTSE350 SE & FTSE350 OTC & FTSE350 ATS & AIM SE & AIM OTC & AIM ATS \\
\hline \multicolumn{2}{|l|}{ b0 } & $-0.764^{* *}$ & -0.201 & -0.218 & -0.273 & $-1.213^{* *}$ & $-0.810^{* *}$ & $-0.996^{* *}$ \\
\hline $\operatorname{Ln}(1+$ NINST $)$ & $+1-$ & $0.347^{* *}$ & $0.477^{* *}$ & $0.539^{* *}$ & $0.532^{* *}$ & $0.304^{* *}$ & $0.336^{* *}$ & $0.329^{* *}$ \\
\hline $\operatorname{Ln}(1+\%$ INST $)$ & $+1-$ & $-0.064^{* *}$ & $-0.102^{* *}$ & $-0.126^{* *}$ & $-0.123^{* *}$ & $-0.117^{* *}$ & $-0.167^{* *}$ & $-0.149^{* *}$ \\
\hline Ln $(1+\%$ INSID $)$ & - & 0.012 & $0.017^{*}$ & $0.018^{*}$ & $0.016^{*}$ & 0.028 & 0.024 & 0.027 \\
\hline Ln (VOL) & + & $-0.119^{* *}$ & $-0.082^{* *}$ & $-0.076^{* *}$ & $-0.073^{* *}$ & $-0.183^{* *}$ & $-0.184^{* *}$ & $-0.178^{* *}$ \\
\hline $\operatorname{Ln}(1+\mathrm{NSEG})$ & - & $-0.140^{* *}$ & $-0.081^{* *}$ & $-0.066^{* *}$ & $-0.070^{* *}$ & $-0.205^{* *}$ & $-0.154^{* *}$ & $-0.174^{* *}$ \\
\hline $\operatorname{Ln}(1+$ NLISTING $)$ & $+1-$ & $-0.022^{*}$ & $0.159^{* *}$ & -0.009 & 0.020 & $0.188^{* *}$ & $-0.048^{* *}$ & 0.015 \\
\hline BIG4 & + & $0.406^{* *}$ & $0.280^{* * *}$ & $0.256^{* *}$ & $0.259^{* *}$ & $0.211^{* *}$ & $0.242^{* *}$ & $0.228^{* *}$ \\
\hline BETA & + & $0.235^{* * *}$ & $0.230^{* *}$ & $0.248^{* *}$ & $0.244^{* *}$ & $0.270^{* *}$ & $0.284^{* *}$ & $0.280^{* *}$ \\
\hline ROE & + & $0.000^{* *}$ & 0.000 & $0.000^{*}$ & 0.000 & $0.001^{*}$ & $0.001^{*}$ & $0.001^{*}$ \\
\hline MKT & + & $0.893^{* *}$ & & & & & & \\
\hline $\operatorname{Ln}(\mathrm{TA})$ & + & $0.136^{* *}$ & $0.044^{* *}$ & $0.050^{* *}$ & $0.051^{* *}$ & $0.355^{* *}$ & $0.349^{* *}$ & $0.357^{* *}$ \\
\hline \multicolumn{2}{|c|}{ CONSUMER_CYCLICAL } & 0.027 & $0.075^{* *}$ & $0.080^{* *}$ & $0.077^{* *}$ & -0.045 & -0.12 & -0.098 \\
\hline \multicolumn{2}{|c|}{ CONSUMER_NON_CYCLICAL } & $-0.137^{* *}$ & $-0.082^{* *}$ & $-0.062^{* *}$ & $-0.068^{* *}$ & $-0.143^{* *}$ & $-0.157^{* *}$ & $-0.163^{* *}$ \\
\hline \multicolumn{2}{|c|}{ ENERGY } & $0.161^{* *}$ & 0.053 & 0.026 & 0.037 & $0.196^{* *}$ & $0.213^{* *}$ & $0.213^{* *}$ \\
\hline \multicolumn{2}{|l|}{ FINANCIAL } & $-0.343^{* *}$ & $-0.201^{* *}$ & $-0.202^{* *}$ & $-0.206^{* *}$ & $-0.537^{* *}$ & $-0.577^{* *}$ & $-0.570^{* *}$ \\
\hline \multicolumn{2}{|l|}{ INDUSTRIAL } & $-0.210^{* *}$ & $-0.153^{* *}$ & $-0.157^{* *}$ & $-0.162^{* *}$ & $-0.333^{* *}$ & $-0.373^{* *}$ & $-0.367^{* *}$ \\
\hline \multicolumn{2}{|l|}{ TECHNOLOGY } & -0.058 & $0.091^{* *}$ & 0.077 & $0.087^{*}$ & $-0.242^{* *}$ & $-0.268^{* *}$ & $-0.266^{* *}$ \\
\hline \multicolumn{2}{|l|}{ UTILITIES } & $-0.293^{* *}$ & $-0.183^{* *}$ & $-0.196^{* *}$ & $-0.194^{* *}$ & $-1.596^{* *}$ & $-1.572^{* *}$ & $-1.627^{* *}$ \\
\hline \multicolumn{2}{|l|}{$\mathrm{N}$} & 3224 & 1412 & 1412 & 1412 & 2107 & 2107 & 2107 \\
\hline \multicolumn{2}{|l|}{ Adjusted R-squared } & 0.83 & 0.67 & 0.66 & 0.66 & 0.47 & 0.46 & 0.46 \\
\hline \multicolumn{2}{|l|}{ Log likelihood } & -7013.55 & -4177.42 & -4203.84 & -4202.95 & -3186.35 & -3191.64 & -3194.02 \\
\hline
\end{tabular}

**, *. Coefficient is significant at the 0.01 and 0.05 level (2-tailed) respectively. Ln: the natural logarithm.

This section reports the results for the model (2) thereby addressing the question whether listing on the main board as opposed to the junior market impacts the number of analysts following a stock? We run the more conservative negative binomial count data regression because the conditional mean and variance of the dependent variable are not equal. To compute robust standard errors, the generalised linear model variation of the negative binomial count data regression method is applied.

In Table 4, the second column reports the estimates of the model (2) for the total sample when using the total number of cross-listings (NLISTING). Columns three to eight estimate model (2) for FTSE350 and AIM companies separately, replacing NLISTING with SE, OTC and ATS in succession. The total sample regression explains about 83\% (adjusted R-squared) of the variance in the number of analysts following a UK listed firm. These results are generally in line with prior empirical results and expectations (e.g., Bhushan, 1989; Hussain, 2000; Marston, 1997) except for \%INST, VOL and NLISTING. However, there are important differences when we break down the results by listing location.

The association between analyst coverage (NANAL) and the percentage of institutional holdings (\%INST) is negative and significant. This is consistent with results from Marston (1997) but in contrast to results from Bhushan (1989) and Hussain (2000). Later, we find evidence that the negative sign is likely due to missing variable bias by failing to control for listing requirements. Return variability (VOL) has a significant negative association with NANAL for the entire sample and for both FTSE350 and AIM companies. If analyst information and public information are more useful in predicting future return than public information alone, then higher return variability is expected to drive higher trading profits. Thus, Bhushan (1989) expects that the aggregate demand for analyst services is an increasing function of a firm's return variability, assuming that the additional cost of information acquisition for firms with higher return variability is not significant. Our result, however, implies that either trading profits are lower or the cost of acquiring information is higher, or both, for the UK listed companies with higher volatility. This discourages analysts from covering more volatile stocks. Our results also show that firm size measured by total assets (TA) has a positive and significant impact on analyst coverage consistent with results from prior studies (e.g., Jiraporn et al., 2012, 2014).

Overall, cross-listing (NLISTING) is negative but the type of trading venue seems to be the salient factor here. The number of listings on stock exchanges (SE) is positively associated with analyst coverage for FTSE350 and AIM companies while the number of over the counter listings is inversely related for AIM companies. The impact of listings on stock exchanges (SE) is consistent with Marston (1997) but in contrast with Eng et al. (2008). Evidently, cross-listing on stock exchanges (SE) enhances analyst coverage likely because more investors trade on the additional stock exchanges and demand more analyst services (Baker, Nofsinger, \& Weaver, 2002). In contrast, less transparent market venues tend to be inversely associated with analysts coverage, possibly because less transparent markets discourage active trading interest and lessen the demand for analyst services. There is also evidence that the industry sector affects the number of analysts following a UK listed company where the energy sector attracts more analyst coverage, especially for the junior market, whereas most other industry sectors attract fewer analysts.

It is remarkable that listing on the main board (MRT) has a significant positive influence on the number of analysts following a UK listed company that is independent of other control variables. This result suggests that one benefit of moving to the main board is that more analysts are likely to follow the firm and potentially this can improve the market for the firm's shares and increase firm value. This implies that listing on the main market increases the aggregate demand for analyst services since companies listed on the main market have wider investors' bases and are more in the public eye (visible) than their AIM counterparts. However, the significance of MRT can be a result of listing requirements because firms listed on the main board have larger market capitalisation and/or larger free float, two attributes that are hypothesised to be positively associated with analyst coverage.

\subsection{An examination of listing requirements}

To examine the impact of listing requirements on analyst coverage, we first replace total assets (TA) with market capitalisation (MCAP) and check the impact on the MRT dummy. Then we add FLOAT and again check the impact on the MRT dummy. The purpose is to show the association between the number of analysts following and each of the two listing requirements, i.e. market capitalisation (MCAP) and free float (FLOAT) for the total sample and for the individual markets by type of cross-listing separately. 
Table 5

Testing for firm size measured by market capitalisation (MCAP).

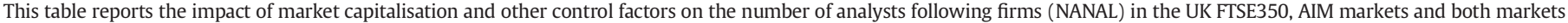
combined using Negative Binomial Count (Quadratic hill climbing) and GLM Robust Standard Errors \& Covariance.

\begin{tabular}{|c|c|c|c|c|c|c|c|c|}
\hline Variable & Expected sign & Total all & FTSE350 SE & FTSE350 OTC & FTSE350 ATS & AIM SE & AIM OTC & AIM ATS \\
\hline \multicolumn{2}{|l|}{$\mathrm{b}_{0}$} & $-1.609 * *$ & $-0.461^{* *}$ & $-0.472^{* *}$ & $-0.533^{* *}$ & $-1.295^{* *}$ & $-1.037^{* *}$ & $-1.180^{* *}$ \\
\hline $\begin{array}{l}\mathrm{b}_{0} \\
\operatorname{Ln}(1+\text { NINST })\end{array}$ & $+1-$ & $0.179^{* *}$ & $0.442^{* *}$ & $0.490^{* *}$ & $0.487^{* *}$ & $0.219^{* *}$ & $0.226^{* *}$ & $0.228^{* *}$ \\
\hline & $0.095^{* *}$ & -0.073 & $-0.087^{* *}$ & $-0.087^{* *}$ & -0.05 & -0.078 & -0.062 \\
\hline \multicolumn{2}{|l|}{$\operatorname{Ln}(1+\%$ INSID $)$} & 0.003 & 0.005 & 0.004 & 0.003 & 0.016 & 0.015 & 0.018 \\
\hline \multicolumn{2}{|l|}{$\operatorname{Ln}(\mathrm{VOL})$} & 0.001 & -0.031 & -0.021 & -0.018 & $-0.126^{* *}$ & $-0.126^{* *}$ & $-0.130^{* *}$ \\
\hline \multicolumn{2}{|l|}{$\operatorname{Ln}(1+$ NSEG $)$} & $-0.083^{* *}$ & $-0.063^{* *}$ & $-0.047^{* *}$ & $-0.050^{* *}$ & $-0.146^{* *}$ & $-0.117^{* *}$ & $-0.116^{* *}$ \\
\hline \multicolumn{2}{|l|}{$\operatorname{Ln}(1+$ NLISTING $)$} & $-0.052^{* *}$ & $0.140^{* *}$ & $-0.028^{* *}$ & 0.001 & 0.011 & $-0.103^{* *}$ & $-0.056^{* *}$ \\
\hline \multicolumn{2}{|l|}{ BIG4 } & $0.357^{* *}$ & $0.271^{* *}$ & $0.249^{* *}$ & $0.251^{* *}$ & $0.249^{* *}$ & $0.266^{* *}$ & $0.254^{* *}$ \\
\hline \multicolumn{2}{|l|}{ BETA } & $0.234^{* *}$ & $0.246^{* *}$ & $0.265^{* *}$ & $0.261^{* *}$ & $0.202^{* *}$ & $0.205^{* *}$ & $0.203^{* *}$ \\
\hline \multicolumn{2}{|l|}{ ROE } & 0.000 & $0.000^{* *}$ & 0.000 & 0.000 & $0.001^{* *}$ & $0.001^{* *}$ & $0.001^{* *}$ \\
\hline \multicolumn{2}{|c|}{ MRT +} & $0.764^{* *}$ & & & & & & \\
\hline \multicolumn{2}{|c|}{$\operatorname{Ln}(\mathrm{MCAP}) \quad+$} & $0.246^{* *}$ & $0.066^{* *}$ & $0.075^{* *}$ & $0.075^{* *}$ & $0.394^{* *}$ & $0.391^{* *}$ & $0.394^{* *}$ \\
\hline \multicolumn{2}{|c|}{ CONSUMER_CYCLICAL } & $0.110^{* *}$ & $0.090^{* *}$ & $0.098^{* *}$ & $0.094^{* *}$ & 0.051 & 0.011 & 0.032 \\
\hline \multicolumn{2}{|c|}{ CONSUMER_NON_CYCLICAL } & $-0.105^{* *}$ & $-0.077^{* *}$ & $-0.056^{*}$ & $-0.062^{* *}$ & $-0.132^{* *}$ & $-0.119^{* *}$ & $-0.130^{* *}$ \\
\hline \multicolumn{2}{|c|}{ ENERGY } & $0.175^{* *}$ & $0.068^{*}$ & 0.040 & 0.050 & $0.249^{* *}$ & $0.243^{* *}$ & $0.247^{* *}$ \\
\hline \multicolumn{2}{|l|}{ FINANCIAL } & $-0.160^{* *}$ & $-0.146^{* *}$ & $-0.137^{* *}$ & $-0.141^{* *}$ & $-0.414^{* *}$ & $-0.440^{* *}$ & $-0.424^{* *}$ \\
\hline \multicolumn{2}{|l|}{ INDUSTRIAL } & $-0.129^{* *}$ & $-0.144^{* *}$ & $-0.141^{* *}$ & $-0.148^{* *}$ & $-0.211^{* *}$ & $-0.224^{* *}$ & $-0.214^{* *}$ \\
\hline \multicolumn{2}{|l|}{ TECHNOLOGY } & $-0.073^{*}$ & $0.078^{*}$ & 0.060 & 0.067 & $-0.365^{* *}$ & $-0.362^{* *}$ & $-0.369^{* *}$ \\
\hline \multicolumn{2}{|l|}{ UTILITIES } & $-0.161^{* *}$ & $-0.131^{* *}$ & $-0.135^{* *}$ & $-0.134^{* *}$ & -1.111 & -1.032 & -1.085 \\
\hline \multicolumn{2}{|l|}{$\mathrm{N}$} & 3197 & 1403 & 1403 & 1403 & 2082 & 2082 & 2082 \\
\hline \multicolumn{2}{|l|}{ Adjusted R-squared } & 0.83 & 0.67 & 0.66 & 0.66 & 0.55 & 0.56 & 0.55 \\
\hline \multicolumn{2}{|l|}{ Log likelihood } & -6831.9 & -4139 & -4157.3 & -4159.2 & -3056.1 & -3043.3 & -3053.6 \\
\hline
\end{tabular}

**, *. Coefficient is significant at the 0.01 and 0.05 level (2-tailed) respectively. $\mathrm{Ln}$ : the natural logarithm.

Table 5 reports the impact of using the listing requirement MCAP rather than the firm size LN (TA) variable. Table 5 is constructed the same way as Table 4 . The second column reports the estimates of model (2) for the total sample when using the total number of crosslistings (NLISTING). Columns three to eight estimate model (2) for FTSE350 and AIM companies separately, replacing NLISTING with SE, OTC and ATS in succession.

Table 5 shows that the association between NANAL and MCAP is positive and significant for all the specifications of the three samples. The introduction of MCAP has sizeably reduced the magnitude of MRT from 0.893 to 0.764 but it is still significant suggesting that listing location is still important even when we control for the larger market capitalisation of main board listed companies. Also, the introduction of MCAP has improved the log likelihood for all samples suggesting that MCAP is a better proxy for firm size. Comparing these results with those shown in Table 4, we find that firm size measured by total assets or market capitalisation is significantly more important as a determinate of analysts' coverage for the junior rather than main board companies $\left(Z\right.$-test $\left.{ }^{8}\right)$. Taken these results together, we conclude that market capitalisation, a parameter used by the exchange to help determine the listing location, is an especially important driver for analyst coverage that itself does not explain the additional coverage provided to main board firms.

Table 5 also reports that the association between analyst coverage (NANAL) and the percentage of institutional holdings (\%INST) is now positive and significant. As the only difference between Tables 4 and 5 is the change in specification of the size variable from assets LN (TA) to the listing relevant market capitalisation MCAP proxy, this change

\footnotetext{
${ }^{8}$ We conduct a Z-test to determine if the LN (TA) in Table 3 and the MCAP in Table 4 is significantly larger for AIM rather than FTSE350 listed stocks finding that both size proxies are significantly larger at the $5 \%$ level for AIM companies. The $Z$ statistics is calculated as follows: $Z=\left(b_{1}-b_{2}\right) / S Q R\left(S E b_{1}^{2}+S E b_{2}^{2}\right)$ : where $b_{1}$ and $b_{2}$ are the coefficients of the slopes of the relevant variables. $S E b_{1}$ and $S E b_{2}$ are the standard errors for $b_{1}$ and $b_{2}$ respectively, and SQR is the square root. We omit the details of this test for the sake of brevity but the results of a similar Z-test are reported in Table 6 that reach the same conclusions concerning the difference in determinates of analysts following for FTSE350 as opposed to AIM listed stocks. Details of the omitted Tables 4 and 5 tests are available from the corresponding author upon request.
}

in sign is likely due to the more discriminatory MCAP variable that provides a better fitting model. ${ }^{9}$

Table 6 next reports the joint influence of MCAP and FLOAT on the number of analysts following a UK listed company. In contrast to Tables 4 and 5, we now utilise the log of the number of listings on stock exchange (SE) as a proxy for cross-listing to make our results more comparable to the existing literature that, evidently, examined the influence of cross-listing on stock exchanges only. In results not reported here, we reach the same conclusions obtained in Table 6 when we use alternative specifications of the number of listings (i.e., OTC and ATS). ${ }^{10}$

In Table 6, MCAP has a positive association with the number of analysts following for all samples and FLOAT has a positive association with NANAL for the total sample and for AIM listed companies. However, FLOAT has an inverse association with NANAL for FTSE350 companies. The Z-test shows that both MCAP and FLOAT have much higher importance for AIM companies. Comparing the results in Table 6 with those obtained in Table 5, we can see that including FLOAT has a marginal impact on the log likelihood of the model. Again \%INST is positive suggesting that, after controlling for listing requirements, acquiring analyst services is not cost effective for individual investors, so more concentrated institutional ownership increases the demand for analyst services. The great point is, however, that even when we control for the listing requirements, MRT is still positive and highly significant indicating that listing location really does matter because even when we control for listing requirements, more analysts follow main board FTSE350 companies than their junior market AIM counterparts.

Clearly, the demand for financial analysts is different for AIM and FTSE350 listed stocks where a larger free float attracts additional analysts following for AIM companies but it has an inverse impact on analysts following FTSE350 companies. One possible reason can be that with a larger float, there is a greater need for monitoring. Table 2B

\footnotetext{
9 There are some other minor differences, for example ROE is no longer significant for the overall sample, but it is true that other than \%INST, no coefficient that was significant in Table 4 became significant of the opposite sign in Table 5.

10 Specifically, analyst coverage increases in stock exchanges listings for the main board stocks and decreases in over the counter market and alternative trading systems for the junior market shares.
} 
Table 6

Testing for MCAP and free float.

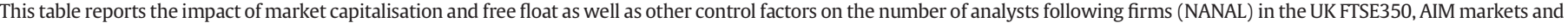
both markets combined using Negative Binomial Count (Quadratic hill climbing) and GLM Robust Standard Errors \& Covariance.

\begin{tabular}{|c|c|c|c|c|c|}
\hline Variable & Expected sign & Total & FTSE350 & AIM & Z-TEST \\
\hline $\mathrm{b}_{0}$ & & $-2.107^{* *}$ & -0.115 & $-2.121^{* *}$ & $4.566+$ \\
\hline $\operatorname{Ln}(1+$ NINST $)$ & $+1-$ & $0.143^{* *}$ & $0.468^{* *}$ & $0.188^{* *}$ & $5.253+$ \\
\hline $\operatorname{Ln}(1+\%$ INST $)$ & $+1-$ & $0.113^{* *}$ & -0.057 & -0.032 & -0.355 \\
\hline $\operatorname{Ln}(1+\%$ INSID $)$ & - & 0.011 & -0.002 & $0.035^{* *}$ & $-1.839+$ \\
\hline $\operatorname{Ln}(\mathrm{VOL})$ & + & 0.007 & $-0.048^{*}$ & $-0.120^{* *}$ & 1.450 \\
\hline $\operatorname{Ln}(1+\mathrm{NSEG})$ & - & $-0.100^{* *}$ & $-0.065^{* *}$ & $-0.153^{* *}$ & $1.739+$ \\
\hline $\operatorname{Ln}(1+\mathrm{SE})$ & $+1-$ & $0.075^{* *}$ & $0.146^{* *}$ & -0.007 & $2.995+$ \\
\hline BIG4 & + & $0.356^{* *}$ & $0.272 * *$ & $0.251^{* *}$ & 0.287 \\
\hline BETA & + & $0.216^{* *}$ & $0.250^{* *}$ & $0.176^{* *}$ & 1.089 \\
\hline ROE & + & 0.000 & 0.000 & $0.002^{* *}$ & $-2.607+$ \\
\hline MKT & + & $0.764^{* *}$ & & & \\
\hline $\operatorname{Ln}(\mathrm{MCAP})$ & + & $0.243^{* *}$ & $0.054^{* *}$ & $0.397^{* *}$ & $-15.654+$ \\
\hline Ln (FLOAT) & + & $0.079^{* *}$ & $-0.096^{* *}$ & $0.205^{* *}$ & $-4.703+$ \\
\hline CONSUMER_CYCLICAL & & $0.102^{* *}$ & $0.092^{* *}$ & 0.040 & 0.620 \\
\hline CONSUMER_NON_CYCLICAL & & $-0.127^{* *}$ & $-0.073^{* *}$ & $-0.145^{* *}$ & 1.071 \\
\hline ENERGY & & $0.176^{* *}$ & $0.076^{*}$ & $0.240^{* *}$ & $-2.303+$ \\
\hline FINANCIAL & & $-0.166^{* *}$ & $-0.144^{* *}$ & $-0.412^{* *}$ & $3.205+$ \\
\hline INDUSTRIAL & & $-0.144^{* *}$ & $-0.136^{* *}$ & $-0.245^{* *}$ & 1.413 \\
\hline TECHNOLOGY & & $-0.072^{*}$ & $0.089^{* *}$ & $-0.408^{* *}$ & $5.452+$ \\
\hline UTILITIES & & $-0.164^{* *}$ & $-0.131^{* *}$ & -1.047 & 1.263 \\
\hline $\mathrm{N}$ & & 3197 & 1403 & 2082 & \\
\hline Adjusted R-squared & & 0.84 & 0.67 & 0.56 & \\
\hline Log likelihood & & -6831.75 & -4135.23 & -3048.54 & \\
\hline
\end{tabular}

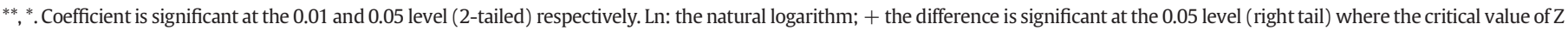

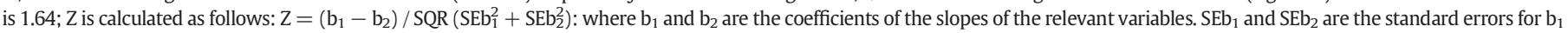

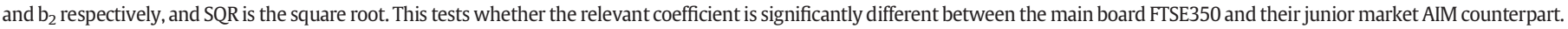

shows that institutional ownership is more dominant for FTSE350 companies. Given the dominance of institutions, internal monitoring can be more effective for main board companies. This can act as a substitute for external analysts, thereby reducing the number of analysts following. However, for AIM listed companies, institutions are less dominant. Moreover, a larger free float implies that the company can upgrade to the main board, thereby attracting additional analysts following.

It is also worth noting that there are clearly different industry effects for the main board and junior markets. It is striking that wellestablished technology firms attract additional analysts following for the main board but attract fewer analysts for recent technology firms listed on the junior market. It is also noteworthy that energy firms are always popular with analysts, but only established consumer cyclical firms listed on the main board have a positive association with the number of analysts following.

To summarise, we discover that parameters that are used by the London Stock Exchange to determine the listing location, specifically market capitalisation and free float, influence analyst coverage. Moreover, market capitalisation and free float have more powerful impacts on analyst coverage for AIM companies than on their FTSE350 counterparts. Nevertheless, even when we include the impact of these listing parameters in our model, firms that are listed on the main board still have significantly higher analyst coverage.

These conclusions raise the possibility that the demand and supply functions for analyst services are not the same for the main board and AIM stocks. A close observation of our most complete model as reported in Table 6, shows that even when we control for listing requirements, many variables have different associations with NANAL depending on the listing location. The number of cross-listings on SE is positive for FTSE350 companies yet it is not significant for the AIM companies and the Z-test shows that this difference is highly significant. The positive association between analyst coverage and the number of institutional investors NINST is significantly more important for main board listed firms while the percentage of insiders' holdings (\%INSID) is only significant for junior market firms. Moreover, the positive influence of profitability (ROE) and the negative influence of the number of lines of business (NSEG) on analyst coverage are significantly higher for AIM companies than their main board counterparts. ${ }^{11}$

Overall, these results suggest important differences between the main board and junior market for the factors that determine the number of analysts following a firm. This implies that the listing dummy could be concealing the differences in the supply and demand functions for the main board and junior markets. Therefore, we should be cautious when pooling observations from these two markets because this can mask individual market differences and yield misleading results.

\section{Concluding remarks}

We conclude that listing location really does matter. Firms listed on the main board attract additional analyst coverage even when we control for the influence of different types of cross-listings and for listing requirements. However, we do find evidence that the demand and supply functions for analyst coverage do differ by the listing location, so that pooling stocks from the main board and junior markets can lead to misleading inferences concerning the determinants of analyst coverage.

In detail, the initial results show that the main factors that drive the number of analysts following a firm in the UK market are broadly similar to other studies in the area, specifically ownership structure, return variability, firm size, cross-listing, audit firm size, systematic risk, and return on equity. In contrast to prior studies, we examine the determinates of analysts following by listing location and find that listing on the main board as opposed to the junior market has a significant positive impact on the number of analysts following that is independent of other control variables. This suggests that one benefit of moving from the junior AIM market to the main FTSE350 market is that the firm can attract more analyst coverage. Potentially, this can improve the market for the firm's shares and increase firm value.

We also examine whether listing requirements have influences on analyst coverage and can explain the significant listing location

\footnotetext{
11 Also, industry effects tend to be more significant for the AIM market.
} 
dummy variable. Specifically, we repeat the analysis by including market capitalisation and free float. We find that market capitalisation and free float have positive and significant associations with analyst coverage for the total sample. We also find that the impacts of both market capitalisation and free float are significantly higher for the AIM listed companies.

Still, even when we control for listing requirements, listing on the main board attracts significantly more analysts following. When examining the results by the listing location, we find that some of the determinants of analyst coverage are conditional on the listing location. For example, additional listings on stock exchanges increase analyst coverage for the main board stocks but not the junior market stocks, yet additional listings on less transparent over the counter and alternative trading systems decrease analyst coverage for the junior market shares but have less effect on the main board stocks. There are other examples. Increases in the number of institutions owing shares increase analyst coverage significantly more for the main board stocks while increases in the percentage ownership by insiders and increases in profitability increase analyst coverage significantly more for the junior market stocks. Therefore, pooling stocks from these different listing locations can mask individual differences between the main market and the junior market and can yield misleading inferences about determinants of analyst coverage by listing location.

Our results are of interest to investors and managers alike in that they improve our understanding of the factors that attract analyst coverage and how they are sensitive to listing location. Our results also show specific characteristics of companies, depending on the listing location, that management can control to attract more analyst coverage. Future research may investigate whether the attributes of analyst forecasts are also conditional on listing location.

\section{References}

Abdallah, A., Abdallah, W., \& Ismail, A. (2012). Do accounting standards matter to financial analysts? An empirical analysis of the effect of cross-listing from different accounting standards regimes on analyst following and forecast error. The International Journal of Accounting, 47(2), 168-197.

Anantharaman, D., \& Zhang, Y. (2011). Cover me: Managers' responses to changes in analyst coverage in the post-regulation FD period. The Accounting Review, 86(6), 1851-1885.

Baik, B., Kang, J., \& Morton, R. (2010). Why are analysts less likely to follow firms with high managerial ownership? Journal of Accounting, Auditing E' Finance, 25, 171-200.

Baker, H., Nofsinger, J., \& Weaver, D. (2002). International Cross-Listing and Visibility. Journal of Financial and Quantitative Analysis, 37(3), 495-521.

Barth, M., Kasznik, E. R., \& McNichols, M. F. (2001). Analyst coverage and intangible assets. Journal of Accounting Research, 39, 1-34.

Bhushan, R. (1989). Firm characteristics and analyst following. Journal of Accounting and Economics, 11(2-3), 255-274.

Boubaker, S., \& Labégorre, F. (2008). Ownership structure, corporate governance and analyst following: A study of French listed firms. Journal of Banking \& Finance, 32(6), 961-976.

Boubakri, N., \& Bouslimi, L. (2010). Analyst following of privatized firms around the world: The role of institutions and ownership structure. The International Journal of Accounting, 45(4), 413-442.

Brennan, M., \& Hughes, P. (1991). Stock prices and the supply of information. Journal of Finance, 46, 1665-1691.

Brooks, C. (2002). Introductory econometrics for finance. Cambridge University Press.

Bushee, B. J., \& Miller, G. S. (2012). Investor relations, firm visibility, and investor following. The Accounting Review, 87(3), 867-897.

Bushman, R., Piotroski, J., \& Smith, A. (2004). What determines corporate transparency? Journal of Accounting Research, 42, 207-252.

Chen, F., Weiss, I. S., \& Zheng, L. (2007). The predictive role of analyst coverage intensity: Evidence from cross-listing in the US. Journal of Contemporary Accounting and Economics, 3(1), 34-57.

Chen, H., Chen, J. Z., Lobo, G. J., \& Wang, Y. (2011). Effects of audit quality on earnings management and cost of equity capital: Evidence from China. Contemporary Accounting Research, 28(3), 892-925.

Clatworthy, M. A., \& Peel, M. J. (2007). The effect of corporate status on external audit fees: evidence from the UK. Journal of Business Finance \& Accounting, 34(1 \& 2), 169-201.
Cliff, M. T., \& Denis, D. J. (2004). Do initial public offering firms purchase analyst coverage with under-pricing? The Journal of Finance, 59(6), 2871-2901.

DeAngelo, L. (1981). Auditor size and quality. Journal of Accounting and Economics, 183-199.

DeFond, M. L., \& Francis, J. R. (2005). Audit research after Sarbanes-Oxley. Auditing: A Journal of Practice and Theory, 24, 5-30.

Doukas, J. A., McKnigh, P. J., \& Pantzalis, C. (2005). Security analysis, agency costs, and UK firm characteristics. International Review of Financial Analysis, 14(5), 493-507.

Eng, L. L., Nabar, S., \& Mian, G. M. (2008). Cross-listing, information environment, and market value: Evidence from U.S. firms that list on foreign stock exchanges. Journal of International Accounting Research, 7(2), 25-41.

Giraldo, M. (2011). Dynamics of analysts' coverage and the firms' information environment. International Review of Financial Analysis, 20(5), 345-354.

Gotti, G., Han, S., Higgs, J. L., \& Kang, T. (2012). Managerial stock ownership, analyst coverage, and audit fee. Journal of Accounting, Auditing \&' Finance, 27(3), 412-437.

Hausman, A. (1978). Specification tests in econometrics. Econometria, 46, 1251-1272.

Hsiao, C. (2002). Analysis of panel data (2nd ed.). Cambridge: Cambridge University Press, London.

Hussain, S. (2000). Simultaneous determination of UK analyst following and institutional ownership. Accounting and Business Research, 30(2), 111-124.

Ireland, J. C. (2003). An empirical investigation of determinants of audit reports in the UK. Journal of Business Finance \& Accounting, 30(7-8), 975-1016.

Jiraporn, P., Chintrakarn, P., \& Kim, Y. S. (2012). Analyst following, staggered boards, and managerial entrenchment. Journal of Banking \& Finance, 36, 3091-3100.

Jiraporn, P., Liu, Y., \& Kim, Y. S. (2014). How do powerful CEOs affect analyst coverage? European Financial Management, 20(3), 652-676.

Jung, B., Sun, K. J., \& Yang, Y. S. (2012). Do financial analysts add value by facilitating more effective monitoring of firms' activities? Journal of Accounting, Auditing E' Finance, 27(1), 61-99.

Kirk, M. (2011). Research for sale: Determinants and consequences of paid-for analyst research. Journal of Financial Economics, 100(1), 182-200.

Lang, M., \& Lundholm, R. (1996). Corporate disclosure policy and analyst behaviour. The Accounting Review, 71, 467-492.

Lang, M., Lins, K., \& Maffett, M. (2012). Transparency, liquidity, and valuation: international evidence on when transparency matters most. Journal of Accounting Research 50(3), 729-774

Lang, M., Lins, K., \& Miller, D. (2004). Concentrated control, analyst following and valuation: Do analysts matter most when investors are protected least? Journal of Accounting Research, 42, 589-623.

Lehavy, R., Li, F., \& Merkley, K. (2011). The effect of annual report readability on analyst following and the properties of their earnings forecasts. The Accounting Review, 86(3), 1087-1115.

Li, K. K. \& You, H. (2015). What is the value of sell-side analysts? Evidence from coverage initiations and terminations. Journal of Accounting and Economics, 60(2-3), 141-160.

London Stock Exchange Group (2014a). Main market factsheet. (August), available online at: http://www.londonstockexchange.com/statistics/markets/main-market/ main-market.htm

London Stock Exchange Group (2014b). AIM market factsheet. (August), available online at: http://www.londonstockexchange.com/statistics/markets/aim/aim.htm

Marston, C. (1997). Firm characteristics and analyst following in the UK. British Accounting Review, 29, 335-347.

Mola, S., Rau, P. R., \& Khorana, A. (2013). Is there life after the complete loss of analyst coverage? The Accounting Review, 88(2), 667-705.

Office of National Statistics (2012). Share ownership: A report on ownership of UK shares as at 31st December 2012. Available at: http://www.ons.gov.uk/ons/rel/pnfc1/shareownership-share-register-survey-report/2012/stb-share-ownership-2012.html

Rajan, R., \& Servaes, H. (1997). Analyst following of initial public offerings. Journal of Finance, 52(2), 507-529.

Rock, S., Sedo, S., \& Willenborg, M. (2001). Analyst following and count-data econometrics. Journal of Accounting and Economics, 30(3), 351-373.

Sabherwal, S., \& Smith, S. D. (2008). Concentrated shareholders as substitutes for outside analysts. Corporate Governance: An International Review, 16(6), 562-577.

Sibilkov, V., Straska, M., \& Waller, H. G. (2013). Do firms use M\&A business to pay for analyst coverage? Financial Review, 48(4), 725-751.

Tendeloo, B. V., \& Vanstraelen, A. (2008). Earnings management and audit quality in Europe: Evidence from the private client segment market. European Accounting Review, 17(3), 447-469.

The Institute of Chartered Accountants in England and Wales (ICAEW) (2007s). Independent viewpoints beyond the myth | Dialogue in corporate governance. Available online at: http://www.icaew.com/search?q=BEYOND\%2520THE\%2520MYTH

US Census (2012). 'Banking, finance, E' insurance: stocks and bonds, equity ownership', table 1201.

Yu, M. (2010). Analyst forecast properties, analyst following and governance disclosures: A global perspective. Journal of International Accounting, Auditing and Taxation, 19(1), $1-15$. 